\title{
VZTAH BIBLE, BIBLICKÉ HERMENEUTIKY \\ A KŘESŤANSKÉ SOCIÁLNÍ ETIKY: \\ METODOLOGICKÉ POZNÁMKY K UTVÁŘENÍ \\ TEOLOGICKOETICKÉ REFLEXE
}

PETR ŠTICA

Sociální etiku lze definovat jako vědeckou disciplínu, která má charakter etiky, jejímž tématem je sociální skutečnost. ${ }^{1}$ Křestanská sociální etika je pak chápána jako teologická disciplína, která se obsahově překrývá s uvedenou charakteristikou sociální etiky a jejíž specifikum spočívá ve faktu, že sociální skutečnosti a jejich posuzování, reflexi a návrhy $\mathrm{k}$ jejich utváření nahlíží a předkládá z perspektivy křestanské víry a teologie. Úkolem křestanské sociální etiky je především analyzovat společenskou a politickou situaci jako celek a přispívat etickými reflexemi, které jsou činěny „ve světle evangelia“, k vyjasnění cílů a mravně přijatelným opcím pro jednání. ${ }^{2}$ Jako teologická disciplína, mající zároveň interdisciplinární charakter, klade na teology náročný požadavek utvářet křestanskou sociální etiku tak, aby na jedné straně neztratila svou vědeckou plausibilitu v širokém odborném diskursu (tj. i v neteologických oborech), ale aby na straně druhé nerezignovala v rámci nároku interdisciplinární spolupráce na svůj teologický charakter.

Sociální problematika, utváření sociálních skutečností a jejich posuzování patří k samotné podstatě poslání křestanských společenství i života jednotlivých křestanů. Uvedenou skutečnost potvrzuje na mnoha místech Kompendium sociální nauky církve, které zdůrazňuje, že sociální etika a sociální oblast představuje jádro života křestanských církví a jednu z priorit v rámci hlásání křestanské zvěsti:

1 Srov. ANZENBACHER, Arno. Křestanská sociální etika: úvod a principy. Brno: Centrum pro studium demokracie a kultury, 2004, s. 7.

2 Srov. GABRIEL, Ingeborg - PAPADEROS, Alexandros K. - KÖRTNER, Ulrich H. J. Perspektiven ökumenischer Sozialethik: der Auftrag der Kirchen im größeren Europa. 2. vydání. Mainz: Matthias-Grünewald-Verlag, 2006, s. 130. 
„,Hlásání a šíření sociální nauky je ve skutečnosti podstatnou součástí poslání církve evangelizovat a součástí křestanské zvěsti, protože toto učení ukazuje její konkrétní důsledky pro život ve společnosti. Každodenní práci a s ní spojený boj za spravedlnost tak zahrnuje do vydávání svědectví pro Krista Spasitele. ${ }^{63}$ Nestojíme tedy před nějakým vedlejším zájmem nebo okrajovým působením, které by se přidružovalo k poslání církve, nýbrž v samotném srdci církevní služby: Prostřednictvím sociální nauky církev zvěstuje každému člověku Boha a mystérium spásy v Kristu. “4 Na jiném místě se dodává: „Šíření sociální nauky církve představuje pastorační prioritu, aby osoby osvícené touto naukou byly uschopněny interpretovat dnešní svět a hledat příslušné způsoby jednání. ,Předávání a šíření sociální nauky je součástí poslání církve hlásat evangelium.“"5

Sociální nasazení křestanských církví, jednotlivých křestanů a skupin věřících, podporované teologickoetickou reflexí, nepatří jen k jádru církevní služby - diakonická sféra představuje spolu s hlásáním Božího slova (martyria) a bohoslužbou (leitúrgia) pilíř života a identity křestanského společenství - nýbrž sociální nauka tvoří rovněž integrální součást evangelizačni služby církve. Zde je třeba podotknout, že pokud církev nejen hlásá, ale také realizuje své sociální a charitativní poslání v rámci společnosti i církve, stává se celé její působení, včetně hlásání evangelia, pro širokou společnost přitažlivější a věrohodnější.

Jednotliví členové celého společenství Božího lidu, kteří jsou Bohem povoláni k utváření světa ke spravedlivější a lidštější podobě, vycházejí při hledání cest k řešení společenských otázek ze specifických náhledů na člověka a na svět ve světle Písma svatého, jímž se jako celé společenství Božího lidu živí a zároveň ho dále předávají, rozvíjejí a aktualizují. Proto je patrné, že v metodologii a reflexi křestanské sociální etiky - ostatně jako teologické etiky a teologie vůbec - hrají Bible, její poselství a hermeneutika svou nezastupitelnou roli.

Nabízí se tedy otázka, jak má vztah křestanské sociální etiky a Bible vypadat a jak se má tento vztah utvářet. Tato otázka je i v dnešní době velmi aktuální a vyžaduje neustálé promýšlení. V následujících odstavcích

3 Kompendium zde cituje ze sociální encykliky JAN PAVEL II. Centesimus annus (1991), čl. 5 (český překlad Sociálni encykliky (1891-1991). Praha: Zvon, 1996, s. 420).

4 PAPEŽSKÁ RADA PRO SPRAVEDLNOST A MÍR. Kompendium sociální nauky církve (2004), čl. 67. Kostelní Vydří: Karmelitánské nakladatelství, 2008, s. 55.

5 PAPEŽSKÁ RADA PRO SPRAVEDLNOST A MÍR. Kompendium, čl. 7, s. 21. Závěrečný citát pochází z: JAN PAVEL II. Sollicitudo rei socialis (1987), čl. 41 (český překlad Sociálni encykliky, s. 398). 
se o takové promýšlení pokusíme. V předkládané studii bude $\mathrm{v}$ základních obrysech nastíněno „místo Bible v křestanské sociální etice“, související metodologické postupy a meze. Metodologicko-hermeneutické poznámky lze považovat za důležité jednak coby východisko pro utváření etické reflexe a formulování eticky normativních či relevantních závěrů týkajících se jednotlivých sociálních skutečností a fenoménů, nicméně uvedené náhledy jsou zásadní rovněž pro chápání celkového profilu křestanské sociální etiky jako teologické disciplíny.

\section{Vztah teologické etiky a Bible v rámci katolické teologie a církevního učení}

Křestanská sociální etika se coby teologická disciplína odvolává na Písmo svaté. Teologie, teologická etika a rovněž křestanská víra z něho čerpají základní jistoty o podstatě a určení člověka a lidské společnosti. V tomto smyslu je „Bible Starého a Nového zákona základní listinou křestanské víry v Boha a v něm zakořeněného křestanského chápání světa. Je tedy v úzkém slova smyslu fundamentem každé křestanské teologie. “6

Křestanská sociální etika je však vzhledem k materii, jíž se ve své reflexi a bádání věnuje, odkázána rovněž na jiné prameny a snaží se profilovat také na úrovni filosofického diskursu jako specifická podskupina sociální filosofie. ${ }^{7} \mathrm{~V}$ pozadí tohoto metodologického zaměření stojí patrně rovněž doba, v níž se křestanská sociální etika začala utvářet jako specifická vědecká disciplína.

Přesto je nezbytné, aby její charakter a profil zůstal teologický, což znamená mj. to, aby se patřičným způsobem opírala o biblické poselství. Na výsostně teologický charakter sociálního učení církve (a křestanské sociální etiky) poukázal Jan Pavel II. ve své encyklice Sollicitudo rei socialis. Sociální učení církve podle něj není „ideologie, nýbrž přesné vyjádření výsledků hlubokého zamyšlení ve světle víry a církevní tradice nad složitou skutečností lidské existence ve společnosti a v mezinárodním kontextu. Jeho hlavním cílem je vyložit tuto skutečnost zkoumáním, zda se shoduje či neshoduje s učením evangelia o člověku a o jeho pozemském

6 HEIMBACH-STEINS, Marianne. Biblische Hermeneutik und christliche Sozialethik. In HEIMBACH-STEINS, Marianne (ed.). Christliche Sozialethik: Ein Lehrbuch 1: Grundlagen. Regensburg: Verlag Friedrich Pustet, 2004, s. 84.

7 Srov. HEIMBACH-STEINS, Marianne. Biblische Hermeneutik, s. 84-85. Marianne Heimbach-Steinsová mezi důvody, které k této profilaci křestanské sociální etiky vedou, uvádí mj. snahu odborníků vyhnout se podezření z teologických předsudků, předpojatosti a nekompetentnosti. 
i nadpřirozeném povolání, aby na základě toho mohlo usměrňovat jednání křestanů. Toto učení tedy nepatří do oblasti ideologie, nýbrž teologie, zvláště teologie morální.“" 8

Křestanská sociální etika a sociální učení církve se začaly rozvíjet zejména během 19. století, především pak na přelomu 19. a 20. století, kdy byla v katolické církvi a teologii převažující, referenční a takříkajíc oficiální doktrínou nauka sv. Tomáše Akvinského oděná do neoscholastického hávu a kdy v otázkách filosofických a teologických východisek a metodologie hrál prim neotomismus se svým poměrně přehlížejícím vztahem k Písmu a zdůrazňováním rozumu a nedynamicky chápaného přirozeného práva. ${ }^{9}$ Teologická etika a morální teologové v tomto období nevěnovali Písmu dostatečnou pozornost a prostor nebo s ním zacházeli nediferencovaně, bez adekvátního přistupu a patřičné konkretizace. Často se biblické výpovědi používaly „pouze pro posílení stanovisek dosažených předtím racionální argumentací, přirozeným právem a učením církevní hierarchie" 10 proto, aby dodatečně legitimovaly a zajistily již existující představy a přesvědčení, ${ }^{11}$ nebo jako určitá „dekorace přirozeně právně orientované reflexe“. Biblické výroky sice byly uváděny, nicméně Bible jako celek prakticky nebyla v rámci teologické etiky předmětem výkladu, natož aby se stala předmětem pečlivé hermeneutiky. Výsledkem byla teologická etika Bibli cizí, na Bibli téměř nezávislá a s Biblí „příliš nepočítajíci“. ${ }^{12}$

K podstatnému obratu dochází na Druhém vatikánském koncilu a přispěním biblického hnutí, které koncilu předcházelo. V dekretu o výchově ke kněžství, pojednávajícím mj. o základní metodologii teo-

8 JAN PAVEL II. Sollicitudo rei socialis, čl. 41 (český překlad Sociální encykliky, s. 398).

9 Užitečné poznámky k tématu vztahu Bible a teologické etiky po Tridentském koncilu, včetně neutěšeného stavu v době 19. a 1. poloviny 20. století, srov. PINCKAERS, Servais. Les sources de la morale chrétienne: sa méthode, son contenu, son histoire. 3. vydání. Fribourg: Éditions Universitaires, 1993, s. 264-288 a 307-311.

10 RUSTON, Robert. Bible a křestanská morálka. Teologické texty 2000, roč. 11, č. 2, s. 67.

11 Srov. WEBER, Helmut. Všeobecná morální teologie. Praha: Zvon, 1998, s. 22.

12 Srov. HÄRING, Bernhard. Frei in Christus: Moraltheologie für die Praxis des christlichen Lebens. Sv. I. Das Fundament aus Schrift und Tradition. Freiburg im Breisgau: Herder, 1989, s. 62. Přestože tato koncepce je dominantní prakticky celou dobu po Tridentském koncilu, objevuje se v 19. století v Německu biblické hnutí usilující o obnovu křestanské morální teologie ve smyslu návratu k evangelijním tématům a morálky života, která vede ke štastnému a Bohem požehnanému životu. Za všechny můžeme uvést teology J. M. Sailera, J. B. Hirschera a F. X. Linsemanna. - Srov. FURGER, Franz. Einführung in die Moraltheologie. Darmstadt: Wissenschaftliche Buchgesellchaft, 1988, s. 11. 
logického bádání a vyučování, se hovoří o místu Písma svatého v teologické reflexi, včetně teologické etiky, následujícími slovy: „Rovněž ostatní teologické předměty se mají obnovit tím, že budou v živějším spojení s Kristovým tajemstvím a s dějinami spásy. Zvláštní péče at se věnuje zdokonalení morální teologie; její vědecké podání at́ se bohatěji živí naukou Písma svatého a osvětluje vznešenost povolání věřících v Kristu a jejich povinnost přinášet v lásce užitek pro život světa." ${ }^{13} \mathrm{~V}$ relevantních koncilních a pokoncilních církevních dokumentech je tato linie potvrzena. Řeč je mj. o tom, že Písmo sv. má „tvořit výchozí bod, trvalý základ a oživující princip celé teologie“14 a že obnova teologické etiky má probíhat vědeckou prezentací živenou Písmem svatým v úzkém kontaktu morálky s ostatními teologickými disciplínami, filosofií a humanitními vědami. ${ }^{15}$

Pokoncilní návrat k Písmu jako k jednomu z hlavních pramenů pro teologickou etiku však není záležitostí samozřejmou a jednoduchou a přináší s sebou celou řadu otázek: Jak je možné chápat vztah biblického poselství a morálky? Jak máme zacházet s biblickým textem? Jak metodologicky postupovat při morálněteologické reflexi? Obsahuje Písmo morální principy, normy nebo pouze povzbuzení (parenezi)? Tyto otázky znějí ještě poněkud ostřeji, jsou-li vztaženy přímo ke křestanské sociální etice: Může Bible představovat pramen pro reflexi křestanské sociální etiky, jestliže ta se vztahuje k věcem soudobým a aktuálním, o nichž autoři, redaktoři či adresáti biblického textu měli sotva nějaké tušení nebo s nimiž neměli žádnou či těžko srovnatelnou zkušenost, a pokud ano, tak ve značně odlišné formě i obsahu? Jak můžeme s tímto základním pramenem víry zacházet př̀i hledání norem v sociální oblasti?

Úvodem je nutno podotknout, že každá etika, aniž by musela být nutně explicitně (jakkoli) nábožensky orientovaná, má svůj vlastní ideový kontext a své vlastní sociální, kulturní a světonázorové pozadí, z něhož vychází a $\mathrm{v}$ jehož rámci jsou prostřednictvím racionální reflexe utvářeny etické normy, postoje a jednání. Každá etika tedy vychází z určitého předporozumění a kontextů, které mohou být reflektovány či nikoli.

13 Optatam totius (1965), dekret o výchově ke kněžství, čl. 16 (český překlad Dokumenty II. vatikánského koncilu, Praha: Zvon, 1995, s. 355).

14 Dei Verbum (1965), věroučná konstituce o Božím zjevení, čl. 24 (český překlad Dokumenty II. vatikánského koncilu, s. 122).

15 Srov. SACRA CONGREGAZIONE PER L'EDUCAZIONE CATTOLICA. La formazione teologica dei futuri sacerdoti (1976), čl. 97-101. In SANCTA SEDES. Enchiridion Vaticanum: documenti ufficiali della Santa Sede 1974-1976. Sv. 5. Bologna: Ed. Dehoniane, 1992, s. 1208-1210. 
Křestanská sociální etika vychází - podobně jako jiné teologické disciplíny - ze specificky teologických pramenů, kam můžeme zařadit Bibli a její živou aktualizaci v životě a výkladu křestanského společenství Božího lidu. Tato živá aktualizace, označovaná jako Tradice, se neidentifikuje jednoduše s učením, s teorií, nebo dokonce s výroky magistéria. Její povaha je mnohem širší a objímá celý život církevního společenství a je mnohem spíše dynamickým a obsahově bohatým bytím nežli jen slovem vypovídajícím o tomto bytí. Vztah mezi Písmem a Tradicí (potažmo magistériem) má podobu kruhu a má vzájemně se prostupující charakter. Písmo a Tradice nepředstavují dva oddělené prameny Zjevení v tom smyslu, že by část Zjevení byla zahrnuta v Písmu a část v Tradici, spíše Tradice představuje jiný způsob předávání toho, co je obsaženo v Písmu. Proto můžeme říci, že Zjevení je cele obsaženo v Písmu i Tradici. ${ }^{16}$ Písmo a Tradice $\mathrm{v}$ uvedeném pojetí utváří specifický kontext pro křestanskou sociální etiku.

Teolog, a tedy stejnou měrou i křestanský sociální etik, by si nejen měl být vědom tohoto ideového pozadí, k němuž se vztahuje, ale zároveň by měl při formulování etické reflexe týkající se sociálních skutečností z těchto pramenů vycházet. Zvláštní respekt k těmto teologickým pramenům však v žádném případě neznamená odklon od rozumu a racionální reflexe nebo zjednodušující, laciný antiintelektualismus. Racionální reflexe zde má své nezastupitelné, ba dokonce primární místo, a to minimálně ve dvojím ohledu:

1. Čtenář/teolog přistupuje k biblickým textům a jejich recepci vždy se svým osobitým racionálním uvažováním, které pátrá po poselství a smyslu textu, po poselství aktualizovatelném a uplatnitelném $\mathrm{v}$ jeho vlastním životě a aplikovatelném rovněž při hledání cest ke spravedlivějšímu uspořádání společnosti. Biblický text ke čtenáři nepřichází zvenku, jako obraz, který by se měl jednoduše obtisknout do srdce čtenáře, ale čtenář naopak jako by sám vstupoval do textu (či možná ještě přesněji formulováno, jakoby vcházel „pod text"). Dovnitř textu přitom čtenář vstupuje nejen se svými rozumovými schopnostmi, ale rovněž se svými zkušenostmi, problémy, individuálními danostmi a sociálními a kulturními specifiky.

16 Podrobnější reflexi lze nalézt ve věroučné konstituci Druhého vatikánského koncilu o Božím zjevení Dei verbum, především ve čl. 2-10, nebo např. v POSPÍŠIL, Ctirad Václav. Hermeneutika mystéria: struktury myšleni v dogmatické teologii. Kostelní Vydří: Karmelitánské nakladatelství, 2005, s. 68-88. Uvedená publikace se sice věnuje metodě $\mathrm{v}$ teologii $\mathrm{z}$ hlediska dogmatické teologie, nicméně pasáže pojednávající o vztahu Písma a tradice mají obecné uplatnění a lze o nich hovořit rovněž v souvislosti s teologickou etikou. 
2. Čtenář/teolog biblické podněty vztahuje na aktuální skutečnost, jejich diferencovanou aplikaci nutně konfrontuje a upravuje ji podle jejich proveditelnosti a důsledků. Uvedený postup tedy není antiracionální ani „bezracionální“, ba přímo naopak - racionální reflexe zde má vždy nezastupitelné místo.

Biblické texty nicméně zůstávají pro křestany a teology základním referenčním bodem - v dynamice vztahování se $\mathrm{k}$ biblickému textu jako k živému Slovu Božímu chtějí křestané přispět k utváření vydařeného života jednotlivých lidí i spravedlivého uspořádání společnosti. ${ }^{17}$ Písmo je pro křestany/teology zavazujícím referenčním bodem zejména proto, že představuje nejzákladnější pramen, z něhož společenství věřících prožívá a zakouší, kým je: jedná se o určité „místo“ a prostředek projasnění identity pro křestany, jejich sebechápání a náhled na svět jako celek. ${ }^{18}$ Ostatně rovněž klasický model autonomní morálky počítá $\mathrm{s}$ tím, že poslední odůvodnění autonomně mravního jednání - podobně jako každé etické reflexe - je možné jen s určitým chápáním člověka a s určitým horizontem smyslu, který pro křestanskou morálku pramení z víry. ${ }^{19}$ V tomto momentě, kdy biblické poselství nabízí svůj originální pohled na člověka a svět, spočívá specifikum teologické a křestanské sociální etiky.

Podle Alfonse Auera nepřidávají ani křestanská víra, ani tradice nic materiálně nového k étosu světa (Weltethos). To, co přináší Bible a křestanská víra nového, co představuje ono proprium christianum, je Kristus jako „nový významový horizont“ či „horizont smyslu“. Nové a specifické jsou tedy nikoli obsahy jednotlivých biblických etických pokynů, ale jejich vztažení na Krista. Z této nové perspektivy, z víry a ze spojení s Kristem (s Bohem) vyrůstají nové motivace k mravnímu jednání. Jde o to integrovat autonomní, racionálně utvářené mravní jednání do naší náboženské vztaženosti k živému Bohu. ${ }^{20}$ Proprium christianum tedy spočívá $\mathrm{v}$ „novém celkovém rozumění, $\mathrm{v}$ němž se vykládá fundamentálně nové určení lidské a světské skutečnosti, dané Ježí̌em Kristem“,21 jinými slovy křestanský pohled na člověka a jeho místo ve světě.

17 Takto metodologicky a myšlenkově utvářená morálka je $\mathrm{v}$ intencích modelu autonomní morálky, jak ji formuloval Alfons Auer. - Srov. AUER, Alfons. Autonome Moral und christlicher Glaube. 2. vydání. Düsseldorf: Patmos-Verlag, 1984.

18 Srov. HEIMBACH-STEINS, Marianne. Biblische Hermeneutik, s. 87-88.

19 Srov. SCHNACKENBURG, Rudolf. Die sittliche Botschaft des Neuen Testaments. Sv. 1. Von Jesus zur Urkirche. Freiburg - Basel - Wien: Herder, 1986, s. 20.

20 Srov. AUER, Alfons. Autonome Moral, s. 177-178.

21 AUER, Alfons. Autonome Moral, s. 212. 
Bible nenabízí bezprostřední normy a etická řešení pro současné sociálněetické problémy, neposkytuje praktické návody k řešení jednotlivých současných situací, není učebnicí nebo návodem k bezprostřednímu mravnímu jednání. Zůstává však živým slovem zaměřeným k Božímu království jako cíli, ${ }^{22}$ zůstává orientací, výzvou či povzbuzením $\mathrm{k}$ revizi našeho jednání a podnětem $\mathrm{k}$ uskutečnitelným činům a k utváření našeho jednání. ${ }^{23}$ Ve vztahu ke křestanské sociální etice můžeme říci, že „Bible nepřináší bezprostřední normativněetické orientace či řešení současných sociálněetických problémů, ale představuje ústřední referenční bod k objevování identity a sebechápání těch, kteří se vztahují k Bohu Bible“.24

Do hry zde vstupuje, jak již bylo řečeno, naše racionalita - s eticky relevantními biblickými texty je třeba zacházet za pomoci věřícího rozumu a se současnou znalostí dané problematiky. Jinými slovy, „ve změněných historických a společenských pomèrech jsou nezbytné rozumové úvahy, které odpovídají Ježíšovu duchu a předpokládají při konkrétních rozhodnutích také znalost věci“. ${ }^{55} \mathrm{~V}$ biblicky orientované etické reflexi nejde o prosté přenesení nebo bezprostřední aplikaci konkrétních biblických norem či parenezí na dnešní jednotlivé př́ípady, ale o nápadné strukturální paralely k otázkám, o nichž dnes pojednává aplikovaná etika. Řešení se hledá jako jistá subtilní výměna mezi obecnými normami a s ohledem na okolnosti a současnost. Nelze přitom pominout, že se většinou jedná nikoli o jediný smysl, ale o pluralizaci možností výkladu. ${ }^{26}$ Písmo nevede vždy jednoduše k jednoznačným řešením, ale pomáhá „odhalovat motivace, formulovat touhy a popisovat horizonty smyslu“. 27

22 K otázce Božího království jako motivačnímu faktoru lidského jednání v sociální oblasti a ideálnímu cíli utváření společenského uspořádání, včetně přiměřených biblických, hermeneutických a teologických závěrů srov. VIVIANO, Benedict T. Království Boži v dějinách. Praha: Vyšehrad, 2008, s. 17-33.

23 Srov. SCHNACKENBURG, Rudolf. Všechno zmůže, kdo vérì: kázáni na hoře a Otčenáš. Praha: Vyšehrad, 1997, s. 67-68.

24 HEIMBACH-STEINS, Marianne. Biblische Hermeneutik, s. 90.

25 SCHNACKENBURG, Rudolf. Horské kázání. In SCHNACKENBURG, Rudolf (ed.). Horské kázání: utopická vize nebo návod k jednáni? [s. 1., 198-?], s. 58 (originální vydání Die Bergpredigt: Utopische Vision oder Handlungsanweisung?. Düsseldorf: Patmos-Verlag, 1982).

26 LESCH, Walter. Bibelhermeneutik und theologische Ethik: philosophische Anfragen. In BONDOLFI, Alberto - MÜNK, Hans J. (ed.). Theologische Ethik heute: Antworten für eine humane Zukunft: Hans Halter zum 60. Geburtstag. Zürich: NZN-Buchverl., 1999, s. 15-16.

27 LESCH, Walter. Bibelhermeneutik, s. 27. 


\section{Biblická hermeneutika a teologická etika}

Při hledání propria teologickoetické reflexe je pochopitelně mimořádně důležitá spolupráce s exegety, kterou zdůrazňuje i dokument Papežské biblické komise o výkladu Bible. ${ }^{28}$ Teolog je v každém př́ípadě při zacházení s biblickými texty odkázán na výsledky exegetických bádání a nesmí zapomínat na kontext, celkové poselství a dynamiku biblické zvěsti. Při pojednávání o etických tématech je přitom patřičnější namísto tázání se jednotlivých míst spíše pátrání po celkovém pohledu a příslušných souvislostech, které je možné správně pochopit pouze prostřednictvím korektní a adekvátní hermeneutiky biblického textu, zohledňující jeho literární druh, historické a teologické pozadí a stupeň závaznosti biblických pokynů. ${ }^{29}$

Eberhard Schockenhoff tuto skutečnost shrnuje následujícími slovy: „Kde biblická exegeze otevírá systematické teologii vědecky spolehlivý přístup k pramenům teologického poznání, musí tyto exegetické znalosti představovat pro dogmatickou a morálněteologickou reflexi základ při její vlastní práci.“30 K nalezení „horizontů smyslu“ potřebují tedy teologové a křest́ané objasňující biblickohermeneutickou práci. ${ }^{31}$ Hermeneutika se přitom odehrává v určitém „plodivém napětí“ ve společné víře těch, kteří biblický text zachytili či kterým byl určen jako původním, prvotním adresátům, a těch, kteří se k tomuto textu vztahují dnes. ${ }^{32}$

Přehnané lpění na historickokritické metodě, která se při soudobé hermeneutice biblického textu předpokládá, by však mohlo vést k určitému „zkamenění“ biblického textu. Bible by se v takovém pojetí mohla stát pouze jakýmsi „textem minulosti“, jehož literární smysl proniknout by pro křestana bylo (či mohlo být) patrně zajímavé, ale na druhou stranu by mohlo jeho poselství být pouze nesnadno aplikovatelné v současné době a v současných podmínkách. Dủležitá je jak četba osobní a zaujatá, tj. ta-

28 Srov. PAPEŽSKÁ BIBLICKÁ KOMISE. Výklad Bible v církvi (1993). 2. vydání. Kostelní Vydří: Karmelitánské nakladatelství, 2007, s. 92.

29 „Otázka závaznosti a způsobu, jímž jsou biblická hodnocení a pokyny závazné, je v posledku otázkou morálněteologické hermeneutiky. Ta ovšem zahrnuje exegetickou otázku, jaký druh závaznosti připisují biblické spisy samy sobě, respektive jaký druh závaznosti dovolují rozpoznat.“- SCHÜRMANN, Heinz. Otázka závaznosti novozákonních hodnocení a pokynů. Teologický sbornik 1995, roč. 1, č. 2, s. 9. SCHOCKENHOFF, Eberhard. Naturrecht und Menschenwürde: universale Ethik in einer geschichtlichen Welt. Mainz: Matthias-Grünewald-Verlag, 1996, s. 236.

31 Srov. EID, Volker. Christlich gelebte Moral: theologische und anthropologische Beiträge zur theologischen Ethik. Freiburg - Wien: Herder, 2004, s. 148.

32 Srov. HEIMBACH-STEINS, Marianne. Biblische Hermeneutik, s. 94. 
ková, která se odehrává s vědomím, že v ní jde o nás a že se dotýká našeho konkrétního života, ${ }^{33}$ tak zároveň četba s pohledem upřeným na realitu světa, uprostřed něhož žijeme.

Proto Walter Lesch při vztahování se k biblickému textu hovoří o třech základních náhledech, k nimž by měl dojít každý, kdo „se odhodlal nasadit si hermeneutické brýle““. ${ }^{34}$ Podle něj musí teolog/čtenář, usilující o korektní hermeneutiku biblického textu, brát zvláštní zřetel: 1. na faktory vzniku biblického textu, včetně literárního a historického pozadí textu (přičemž odhalení literárního smyslu nemusí být zcela jednoznačné nebo „jediné možné“), 2. na dějiny recepce textu (tradici) a 3. na dnešní „horizont chápání“.

Tento horizont chápání nelze chápat nadosobně, nýbrž pouze v aktivním vztahu člověka jako věřícího, myslícího a poznávajícího subjektu, který k textu přistupuje se svým předporozuměním, se svými otázkami a vlastními problémy. Skutečnost tzv. „osobní četby“ implikuje zároveň mnohost čtení a chápání textu. K tomu je třeba podotknout, že stejně jako neexistuje jediný, „objektivní“ čtenář, neexistuje ani jediné beze zbytku správné čtení a chápání biblického textu. Při snaze o četbu a porozumění biblického textu nejde o pouhé dešifrování původně myšleného, nýbrž jde „o metodicky kontrolovanou pluralitu možností interpretace“. ${ }^{35}$

Chápeme-li biblické poselství jako hermeneutiku lidských zkušeností, pak je patrné, že potřebujeme nejen poctivou hermeneutickou práci, ale že se chápání biblického poselství rodí při aktualizaci Písma v interakci s dnešní zkušeností života a víry. „Naše vlastní, zprvu ambivalentní a víceznačné zkušenosti vyžadují interpretaci a objasnění, nemají-li zůstat ryze subjektivní. Právě k tomu účelu mohou biblické texty poskytnout pomoc jako svědkové zkušenosti víry. Do té míry představuje celé biblické poselství hermeneutiku lidských základních zkušeností; mezi zkušeností dosvědčenou v Bibli a dnešní lidskou zkušeností existuje tedy souvislost. [...] Chce-li někdo ostatním umožnit přístup k textům Zjevení, ale i k obsahu smyslu mravních norem, nestane se to na ryze intelektuální bázi; teprve když jednotlivec pozná v příslušných výpovědích vlastní životní možnost a dá se vést vlastními zkušenostmi, otevře se pro něho přístup k vnitřnímu osvojení těchto výpovědí.“36

33 Srov. HELLER, Jan. Podvečerni dékováni: vzpominky, texty a rozhovory. Praha: Vyšehrad, 2005, s. 199.

34 Srov. LESCH, Walter. Bibelhermeneutik, s. 15.

35 LESCH, Walter. Bibelhermeneutik, s. 16.

36 GRÜNDEL, Johannes. Horské kázání jako orientace pro naše jednání: k obnově morální teologie „z učení Písma“. In SCHNACKENBURG, Rudolf (ed.). Horské kázání, s. 93. 
Slova Bible mohou při hledání správné morálky různým zpo̊sobem upozorňovat a přivádět $\mathrm{k}$ zamyšlení, mohou zneklidňovat nebo povzbuzovat, vybízet k úvahám, zastavovat je či je prohlubovat. ${ }^{37} \mathrm{k}$ „osobní“ četbě Písma patří ze své podstaty nechat se Božím slovem ovlivňovat a měnit. Nejde však „o to, abychom se v Bibli našli sami, nýbrž o to, aby nás našla ona, či ještě přesněji, aby nás Biblí jako svým nástrojem našel Bůh. Nejde o to, vkládat se do ní, nýbrž být jí zastižen tam, kde opravdu jsem. To znamená spíše než se v ní hledat, raději se jí vystavovat.“38

Biblické texty přitom pochopitelně nemají být vykládány nekontextuálně, neracionálně, ahistoricky a fundamentalisticky. Zároveň nemají být Boží slovo ani etické pokyny v Bibli obsažené chápány a přijímány legalisticky, nýbrž spíše intencionálně a aproximativně, jinými slovy je důležité vystihnout jádro či úmysl dané normy a $\mathrm{k}$ tomuto úmyslu se přibližovat, což je ostatně rovněž morálněteologická hermeneutika, kterou používá apoštol Pavel. ${ }^{39}$ Teologicky zodpovědná vztaženost k biblickým textům si musí být vědoma souvislostí a hranic biblické argumentace.

\section{Funkce biblických textů v rámci vztahu teologické etiky a Bible}

Uvedené závěry lze beze zbytku vztáhnout na oblast křestanské sociální etiky. Marianne Heimbach-Steinsová popisuje v rámci vztahu Bible a teologické, respektive křestanské sociální etiky čtyři funkce, které Písmo ve vztahu ke křestanské sociální etice má. ${ }^{40}$ Jedná se o:

- heuristicko-hermeneutickou funkci - biblické texty jsou užívány v případě, kdy se jedná o základní orientace křestanské antropologie a etiky;

- odůvodňující funkci - biblické motivy a místa mohou být v některých př́padech uváděny přímo jako odůvodněni některých antropologických a etických náhledů (např. odvolání se na Gn 1,26-28 pro odůvodnění myšlenky lidské důstojnosti v určitých modelech teologické antropologie);

37 Srov. WEBER, Helmut. Všeobecná morální teologie, s. 23.

38 HELLER, Jan. Podvečerni dèkování, s. 200.

39 Srov. SCHÜRMANN, Heinz. Otázka závaznosti, s. 11-12. Jako ilustrativní př́íklad si můžeme vzít Ježíšů radikální pokyn o nerozlučitelnosti manželství (Mk 10,11par) a Pavlovu aplikaci tohoto Ježíšova slova a „ideálu“ aproximativním způsobem do situace prvokřestanské církevní obce v 1 Kor 7 . K tématu srov. rovněž VIRT, Günter. Moraltheologie. In ROTTER, Hans - VIRT, Günter (ed.). Neues Lexikon der christlichen Moral. Innsbruck - Wien: Tyrolia-Verl., 1990, s. 529.

40 Srov. HEIMBACH-STEINS, Marianne. Biblische Hermeneutik, s. 104. 
- senzibilizující funkci - biblické obrazy a texty mohou posloužit k motivaci a senzibilizaci v etické dimenzi daného chování či v otázkách hledání cest k spravedlivému uspořádání společnosti (např. argumentace vycházející z Ježíšových postojů vůči chudým a marginalizovaným jako předobraz pro etické chování) a mohou představovat parenezi pro eticky zodpovědné jednání v oblasti individuální i sociální;

- kulturnědějinnou funkci orientovanou na recepci - k biblickým textům se můžeme vztahovat rovněž za tím účelem, abychom vylíčili souvislosti působeni textu $v$ déjinách, $v$ tradici a kultuře (např. změnu v recepci výroků z Gen 1-3 o vztahu obou pohlaví).

Biblické poselství se $\mathrm{v}$ tomto směru stává především určitou základnou pro vidění, orientaci a porozumění okolnímu světu a člověku, jeho určení a postavení ve světě, vše z perspektivy křestanské víry v trojjediného Boha, která implikuje rovněž základní principy pro životní praxi jak na individuálněetické rovině, tak na rovině sociálněetické. ${ }^{41}$

\section{Křesṫanská sociální etika a spolupráce s neteologickými vědeckými disciplínami}

Písmo na základě obrazu Boha a člověka prezentuje určité fundamentální principy, orientaci a postoje. ${ }^{42}$ Protože však tyto postoje nejsou dostatečně konkretizovány, potřebují diferenciaci, konkretizaci a aktualizaci na rovině filosofického diskursu, který nejen používané pojmy a principy prohlubuje, ale na základě dialektiky a plurality názorů zřetelnějším způsobem ukazuje místo a vyjasňuje obsah pozice vycházející z křestanské víry a předporozumění.

Zároveň však může být tato „filosoficky diferencovaná křestansko-sociálněetická kompetence vztažena na konkrétní sociální problémy teprve tehdy, když se seznámí s příslušným empirickým materiálem získaným ve speciálních vědách, což je prakticky možné jen ve spolupráci s odpovídajícími vědními disciplínami“ ${ }^{43}$ Nejedná se o vztah nadřazenosti teo-

41 Srov. ANZENBACHER, Arno. Křest'anská sociální etika, s. 15-16. Srov. rovněž MARX, Reinhard - WULSDORF, Helge. Christliche Sozialethik: Konturen - Prinzipien Handlungsfelder. Paderborn: Bonifatius, 2002, s. 31.

42 Někdy tyto postoje bývají označovány jako fundamentální biblické opce, jedná se např. o opci pro chudé, slabé a marginalizované, opce pro svobodu a osvobození, pro větší spravedlnost či zachování stvoření, ale rovněž např. o opci pro jiné, jak uvádí Marianne Heimbach-Steinsová. - Srov. HEIMBACH-STEINS, Marianne. Biblische Hermeneutik, s. 107.

43 ANZENBACHER, Arno. Křestáanská sociální etika, s. 31. Podrobněji srov. MARX, Reinhard - WULSDORF, Helge. Christliche Sozialethik, s. 37-51. 
logie nad ostatními vědami. Vztah mezi církví a světem nelze chápat jako jednostranný vztah církve učící (ecclesia docens) vůči vyučovanému světu (mundus discens). Ve skutečnosti se má jednat o dialogický vztah vzájemného obohacování a naslouchání. ${ }^{44}$

Mravní jednání a eticky zodpovědné posuzování a utváření sociálních skutečností se odehrává vždy v oblasti podmínek empiricky věcných obsahů, které jsou relevantní pro tu kterou konkrétní skutečnost. Proto je v rámci křestanské sociální etiky možné dosáhnout patřičného cíle jen při co nejhlubším poznání empirické oblasti podmínek, o nichž pojednávají specializované vědy, které můžeme shrnout pod označení humanitní vědy. Není možné něco považovat a uznávat za mravní, pokud to odporuje rozumu a spolehlivému poznatku jednotlivých věd.

Etika (včetně teologické etiky) však jde ještě dále: Jelikož nemá svůj vlastní základ v empirických danostech, ale v určení člověka jak v jeho individuální danosti a osobním rozvoji („osobni“ dobro, štěstí), tak jako tvora společenského, který je svou podstatou vkořeněný do sociální skutečnosti a sítě společenských vztahů a procesů („společné“ či „obecné“ dobro), plní etika v tomto ohledu vůči specializovaným empirickým vědám rovněž funkci kritického korektivu. Etické principy nelze formulovat vycházeje pouze a čistě $\mathrm{z}$ empirických daností. ${ }^{45} \mathrm{~V}$ této souvislosti se hovoří o „vzájemné funkci strážce“ (kritische Wächterfunktion) empirických věd a etiky. ${ }^{46}$

\section{Závèr}

Jaký je tedy vzájemný vztah různých pramenů křestanské sociální etiky ${ }^{47} \mathrm{~V}$ ideálním př́padě se vzájemně doplňují a ukazují si své hranice

44 Srov. SCHILLEBEECKX, Edward. Von der theologischen Tragweite lehramtlicher Verlautbarungen über gesellchaftspolitische Fragen. Concilium: Internationale Zeitschrift für Theologie 1968, roč. 4, č. 6-7, s. 413.

45 Pomíjíme zde fakt, který byl uveden již dříve $\mathrm{v}$ jiné souvislosti, totiž že fakticky za každou filosofií, ale i za většinou závěrů v oblasti empirických věd stojí nějaké předporozumění, „světonázor“ či pohled na člověka a na svět, ačkoli namnoze bývá nereflektovaný.

46 KORFF, Wilhelm. Empirie. In HUNOLD, Gerfried W. (ed.). Lexikon der christlichen Ethik. Sv. 1. A-K. Freiburg im Breisgau: Herder, 2003, s. 373-374.

47 V rámci křestanské sociální etiky - jak vysvítá i z uvedeného textu - bývají uváděny tři prameny, které jsou pro její odborný diskurs konstitutivní: 1. teologie (kde výsadní roli představuje Bible a přiměřená hermeneutika a interpretace jejího poselství v rámci tradice a živého církevního společenství), 2. etika (v nejširším slova smyslu; myslí se zejména na filosofickou etiku) a 3. sociální a empirické vědy. - Srov. GABRIEL, Ingeborg - PAPADEROS, Alexandros K. - KÖRTNER, Ulrich H. J. Perspekti- 
a meze. ${ }^{48}$ Je však patrné, že součást teologickoetické reflexe by mělo tvořit vždy, nakolik je to možné, pojednání o biblických podnětech relevantních pro eticky zodpovědné hodnocení daného fenoménu, které má v každém případě pečlivě zohledňovat výše uvedené hermeneutické a metodologické nezbytnosti, předpoklady a postupy.

Bible představuje základ teologické etiky, kterou má inspirovat, motivovat a ovlivňovat. Sociálněetická recepce biblických výpovědí však musí nutně podléhat komplexnímu hermeneutickému postupu. Znalost historického kontextu vzniku biblických textů a spolehlivé poznatky historickokritické exegeze stejně jako reflexe vlastního současného filosofického a individuálního předporozumění jsou naprosto nezbytné. Interpretace biblických textů se sociální relevancí pro současnost vyžaduje interdisciplinární teologickou spolupráci, ale rovněž znalost soudobého společenského kontextu a spolupráci s přŕslušnými vědami neteologickými. ${ }^{49}$

Tato studie byla započata stručným představením charakteristiky a profilu křestanské sociální etiky. V návaznosti na to, co bylo řečeno, lze na závěr uvedenou charakteristiku následujícím způsobem rozšiřit: Křestanskou sociální etiku je možné definovat jako svébytnou teologickou disciplínu, která si klade za cíl ve světle křestanského Zjevení, tzn. zejména ve světle biblicky a teologickoantropologicky orientovaného a racionálně uchopeného diskursu, promýšlet a předkládat etické reflexe sociálních skutečností, sociálních institucí, uspořádání společnosti, sociálních jevů atp. V rámci této reflexe hrají Bible, biblické poselství a jeho patřičná hermeneutika zcela zásadní úlohu.

\section{Petr Štica (1980), Katedra teologické etiky a spirituální teologie KTF UK}

ven, s. 133-136. Bible a tradice církevního společenství víry tvoří specifický kontext, v němž „se křestanská etika utváří a v němž získává svůj vlastní profil - podobně jako je formulována $\mathrm{v}$ určitém sociálním, kulturním a světonázorovém nelibovolném kontextu např. etika marxistická, konfuciánská či postkřestanská.“ - HEIMBACH-STEINS, Marianne. Biblische Hermeneutik, s. 85. Judith (ed.). The New Dictionary of Catholic Social Thought. Collegeville (Minnesota): Liturgical Press, 1994, s. 862.

49 Srov. GABRIEL, Ingeborg - PAPADEROS, Alexandros K. - KÖRTNER, Ulrich H. J. Perspektiven, s. 133-134. 


\begin{abstract}
PETR ŠTICA

Relation of the Bible, Biblical Hermeneutics and Christian Social Ethics: Methodological Remarks on Forming a Theological-ethical Reflection
\end{abstract}

The aim of the article is to present the relationship between Christian social ethics and the Bible as well as the related methodological approaches and limits. A correct handling of the biblical texts in theological ethics implies a differentiated approach. This includes first the knowledge of the complexity that arises when applying biblical texts to the ethical reflection of contemporary problems, secondly the familiarity with biblical hermeneutics, and thirdly the interdisciplinary cooperation with theological as well as non-theological sciences. The presented thoughts should contribute to a better understanding of Christian social ethics as a theological discipline as well as its methodological procedure.

Key words

Christian social ethics, Bible, biblical hermeneutics 